\title{
FACTORS AFFECTING THE DECISION TO CHOOSE SCHOOL OF ACUPUNCTURE
}

\author{
Imrok Atus Sholihah'), Hanung Prasetya' ${ }^{2}$, Vitri Widyaningsih ${ }^{3}$ \\ 1)Masters Program in Public Health, Universitas Sebelas Mare \\ 2)Health Polytechnics, Ministry of Health Surakarta \\ ${ }^{3}$ Faculty of Medicine, Universitas Sebelas Maret
}

\begin{abstract}
Background: Education paves for students to help them attain the right knowledge they require to make a better life out for themselves and for the society around them. There are many factors and variables that need to be considered when making the decision to choose school. This study aimed to examine factors affecting the decision to choose school of acupuncture.

Subjects and Method: A case control study was conducted in Health Polytechnic Ministry of Health Surakarta, Soepraoen Polytechnics in Malang, and Academy of Acupuncture Surabaya. A sample of 300 college students was selected by stratified random sampling. The dependent variable was decision to choose school of acupunc-ture. The independent variables were career guidance, academic program, education cost, financial support, college reputation, college promotion, parental support, and location. The data were collected by questionnaire and analyzed by a multiple logistic regression.

Results: The decision to choose school of acupuncture increased by good career guidance $(\mathrm{OR}=19.39 ; 95 \% \mathrm{CI}=3.84$ to $97.84 ; \mathrm{p}<0.001)$, good academic program $(\mathrm{OR}=11.69 ; 95 \% \mathrm{CI}=$ 2.57 to $53.19 ; \mathrm{p}=0.001)$, low education cost $(\mathrm{OR}=11.89 ; 95 \% \mathrm{CI}=2.68$ to $52.75 ; \mathrm{p}=0.001)$, high college reputation $(\mathrm{OR}=10.71 ; 95 \% \mathrm{CI}=2.16$ to $53.22 ; \mathrm{p}=0.004)$, good college promotion $(\mathrm{OR}=6.03 ; 95 \% \mathrm{CI}=1.40$ to $25.93 ; \mathrm{p}=0.016)$, financial support $(\mathrm{OR}=22.66 ; 95 \% \mathrm{CI}=4.45$ to 115.46; $\mathrm{p}<0.001)$, strategic location $(\mathrm{OR}=9.54 ; 95 \% \mathrm{CI}=2.35$ to $38.68 ; \mathrm{p}=0.002)$, and strong parental support $(\mathrm{OR}=26.84 ; 95 \% \mathrm{CI}=5.74$ to $125.52 ; \mathrm{p}<0.001)$.

Conclusion: The decision to choose school of acupuncture increases by good career guidance, good academic program, low education cost, high college reputation, good education promotion, financial support, strategic location, and strong family support.
\end{abstract}

Keywords: school of acupuncture, decision

\section{Correspondence:}

Imrok Atus Sholihah, Pascasarjana Ilmu Kesehatan Masyarakat, Universitas Sebelas Maret, Jalan Ir.Sutami 36A, Surakarta, Jawa Tengah, Indonesia. Email: imrokatussholihah6@gmail.com. Mobile: +6281225210252.

The $7^{\text {th }}$ International Conference on Public Health Solo, Indonesia, November 18-19, 2020 | 354 https://doi.org/10.26911/the7thicph.04.39 